\title{
Beyond Westminster: Thinking the Aotearoa/New Zealand Way of Governing
}

\author{
Bill Ryan
}

Something intriguing is going on within the political executive. In response to emerging conditions of governing in the late 20th and early 21 st century in countries like New Zealand, some public servants are acting in new ways that are quite different from certain key prescriptions of the traditional, Westminster-derived constitutional framework on which our polity is based. The fact of these changes is interesting enough, but, surprisingly, few people talk about it - 'surprisingly' because these new ways of working cause tensions that are known (in tacit practice) but remain unacknowledged (in discourse). This paper identifies some of these changes and considers their implications. ${ }^{1}$

These emerging changes revolve around the manner in which public servants relate to and work in practice with clients, stakeholders, providers and others in 'policy networks', but in a manner that causes unresolved tensions for the officials involved. I argue that these shifts are entirely appropriate given the societal changes they reflect, and, as such, should be regarded as democratically progressive; they signal another significant development beyond our Westminster foundations and come at a time when it is important symbolically and constitutionally to look forward to the 21 st century rather than backwards. On that basis, there is much to be gained by recognising these new realities and consciously articulating what we want and believe to be an Aoteaoroa/New Zealand way of governing, particularly regarding the relationships and activities that constitute the 'public service' and the 'policy process'.

It should be noted that this paper does not deal with the full array of recent and emerging changes to the Westminster foundations of our polity. Several of them (e.g. the shift away from a first-past-the-post to a mixed-

In contrast to much public administration analysis, this analysis focuses on enacted practice rather than the institutional framework. In that respect, this analysis is sociological and political in perspective and focuses on the (often tacit) rules of action underlying the work of public servants (Giddens, 1984). member-proportional electoral system; the role and function of associate ministers; the inclusion in cabinet of non-government ministers; the right of coalition parties in government to break with cabinet solidarity) have been noted and discussed elsewhere (e.g. Palmer and Palmer, 2004; White, 2005).

\section{The public servant according to Westminster}

The classic Westminster image of the public servant is that of an anonymous, neutral and loyal official, embedded in a set of hierarchical, rule-driven positions and practices, technically skilled in analysis, administration and management, and serving the government of the day by providing advice and implementing government decisions to the best of his or her ability (see, for example, Cabinet Office, 2001; State Services Commission, 1995). Collectively, the public service is understood to be the technical arm of the political executive.

This model contains certain assumptions about the policy process, the manner in which it is to be conducted and the role of the public servant in it. It assumes a linear and technical process that is closed and vertically-aligned. Public issues appear on the policy agenda via various routes (e.g. research findings drawn to the attention of government, party manifestos, public controversies to which government is forced to respond) but, at a certain point, the minister of cabinet commits to and prioritises particular issues. Public servants then research these issues, and identify and test various options to deal with them. They conduct research and analysis - the expert application of various theories and methodologies to aid decision making - and present the outputs of their deliberations to the ministry. Ministers consider these options, filtering them with their ideologies, values and electoral concerns, and reach a decision, which public servants then implement. In that sense, the Westminster-based policy process combines 
technical and political rationality within the executive, the public servant constituted according to the former and the minister according to the latter, with the former subordinated to the latter.

Policy analysis and advising is 'backroom' work. Even the implementation of policy as traditionally defined, wherein a much higher proportion of work is 'front counter', open to public gaze and subject to interpersonal influences, it is prescribed in terms of technical expertise in administration of legislation, its application in particular cases, and the accountable management of resources and systems. External relationships such as consultation over policy with interested parties - usually also experts or representatives, and occasionally clients or representatives advocating on their behalf - is handled by ministers and not public servants.

It has been argued for some time that New Zealand had preserved a remarkably 'pure' version of the Westminster conventions in its political system, but developments such as the introduction of associate ministers, the replacement of the first-past-the-post electoral system and the qualification of cabinet solidarity indicate that this is no longer the case. Equally, from the 1970s onwards some intra-executive relationships took on a character quite unlike the simple subordination of the classic, abstract model: certain ministers understood the value of internal and robust debate between themselves and senior officials, relied on their mutual interdependence, and realised the benefits to be gained by balancing technical and value-based decision criteria. In these cases, depending on the issue, the ministersenior official relationship was one of 'teamwork', albeit one wherein the minister would have the last word (James, 2002). Equally, beyond focusing merely on technicalities, senior officials would often exercise a degree of 'nous' in reading the broad social, economic and political context before offering their advice (not the partisan politicisation of advice but a calculation of what might be achievable given the context). And as interest group politics' became accepted, officials sometimes maintained working relationships, albeit at arm's length, with peak professional, industry, provider and client groups and/or their representatives as required, on behalf of the minister. Later, as 'new public management' took hold, senior officials became more used to being in the public limelight of parliamentary and media scrutiny and lost some of their anonymity as a result.
In short, in the final decades of the 20th century anonymity, neutrality and loyalty for senior officials took on more complex, nuanced meanings, and in some cases diminished, and the line between politics and administration blurred significantly, although did not disappear. On the other hand, where newly-appointed ministerial advisers became increasingly prominent in developing new policies for government, some senior officials came to feel they were being pushed back into a role closer to the classic prescription, although in other situations collaboration between advisers and officials may now becoming more common (Eichbaum and Shaw, 2005). Further, whilst the so-called 'New Zealand model of public management' freed up chief executives and senior managers in various managerial respects, they were still bound into a variation on the classic Westminster theme of formal subordination to the minister via output-focused performance contracts. As a broad generalisation, therefore, we can say that Westminster-derived constitutional principles continued to underpin minister-senior official relationships - and set the top-down framework for the conduct of officials more generally - at least until very recent times, and probably still do (James, 2002).

The shifts in public sector practice focused on in this paper, however, are not emerging in the direct relationships between ministers and senior officials. They are arising in the complex relationships emerging between lower-level officials and others involved in the policy process. As will be seen shortly, some of these reveal characteristics that are not consistent with the details of the classic model identified above, although it is difficult to be precise on this point. Documents that might be expected to articulate the norms of official conduct, such as the State Services Commission's Public Service Principles or the current Cabinet Manual, seem to be silent when it comes to the operational detail, and present what seem to be principles derived logically from the overall political relationships at the core of the Westminster conventions. ${ }^{2}$ The point raised by this paper, however, is that these emerging changes are altering the realities of public service in contemporary

2 It should also be noted that the current Cabinet Manual has not been updated since 2001 and the SSC Principles, Conventions and Practice guidance series documents have been withdrawn from the SSC website (see http://www.ssc.govt.nz/display/Glossaryltem. asp?id=104\&this window) on the basis that 'a considerable amount of content relating to process and practice is no longer current'. 
New Zealand from the bottom up. As Colin James in The Tie That Binds (2002, p.75) has noted:

The principles do seem to have lost some of their force and/or no longer to describe actual practice. This risks incredulity and disrespect among lower-level public servants.

The contributors to The Tie That Binds felt generally that there was no need for a 'reformulation' of these principles. This paper, however, argues otherwise.

\section{Emerging trends: officials in policy networks}

Empirically, today the precise form of the policy process in any instance varies according to the government of the day, the particular minister, the government and nongovernment agencies involved, and the complexity and public interest in a particular policy field. There are some cases wherein the process is remarkably like the simple, classic model; others look like a teamwork model.

However, there are ample signs in New Zealand now of what seems like a quite different approach, wherein the constituent relationships and practices - and, hence, the role of the public servant - are quite different. These pockets of emerging practice are found primarily in arenas where groups of citizens have a strong interest in public policy and participate as professionals and experts in their own right; and where government agencies (the leading agency and others, including other levels of government) are involved necessarily in extensive and intensive relationships with individuals and groups. Any and all of clients, stakeholders, providers, intermediaries, representatives, researchers, observers, advocates, critics and opponents may be involved. These relationships are played out in multiple settings in interactions large and small, and occur in a constant buzz of activity. These are the newly emerging 'policy networks'. They can be found in policy development, implementation and evaluation, and in a wide range of policy arenas, such as social policy, including health and education; in policy relating to children, family and the aged; taxation; justice and corrections; regional and economic development; in local government, and in the community sector.

Sometimes, depending on whether they choose to remain above or to join in the fray, ministers, their advisers and relevant parliamentary committee members will also participate directly in these networks in non- parliamentary settings (e.g. conferences and seminars). Otherwise, they play their constituted role as decision makers in the formal setting of Parliament or cabinet, a setting wherein relationships between the minister and public servant are more traditional; but, since these places too are increasingly part of a continuum of spaces wherein the policy network functions, neither can escape the legacy of obligations built up within and around the network, and which impinges upon both the public servant and the minister in definite and determining ways.

In short, we are seeing the emergence in New Zealand of policy networks as a significant and sometimes essential vehicle for realising the policy process - a widely discussed development in contemporary democracies (e.g. Howlett and Ramesh, 1995; see also Rhodes, 1997; Sabatier, 1988; for a New Zealand discussion and examples of the emergence and character of networks, Gray, 2002; and Ministry of Social Development, 2003). What is not often discussed, however, are the assumptions, practices and effects of policy networks, particularly in relation to the changing role of the public servant, the constitutional implications of these developments, their appropriateness for the 21 st century, and how we should approach them - which is what this paper tries to do. ${ }^{3}$

\section{Sociological realities in policy networks: the social (re)constitution of networked officials}

It is a simple sociological fact that individuals may enter into new types of relationships in a particular, previously constituted role but, to establish and build these new relationships, they will need to negotiate new rules of behaviour with other participants that will necessarily modify aspects of their pre-existing role. And to maintain and build these relationships over time, they will need to reproduce these new ways of acting to the point where they become routinised, internalised and experienced as mutual obligations (i.e. as new or variant role prescriptions). They will be penalised by the other participants if these new ways of acting are not repeated.

3 The following discusses the characteristics of policy networks as 'ideal-types': i.e. presents them in the form of typifications that capture the essential features of the phenomenon in focus, as abstracted from known instances. In that respect the typology is 'idealised'. Few empirical instances will evidence all of these imputed features or the internal coherence implied by this analysis. 
Moreover, if these new role prescriptions are carried over into other roles, contradictions and conflicts can arise in those settings.

This paper argues that this effect is having an impact on public servants as they participate increasingly in today's policy networks. They are finding that, to be effective in the complex world of policy, they must act in ways that go beyond the traditional prescriptions and proscriptions, which, as previously noted, tend to focus on minister/government-official relationships and say little about the operational realities of the policy process. Inevitably, this effect is feeding back into conceptions of 'how to act' as a public servant, making some of the founding principles seem unreal and unhelpful. Consequently, significant tensions arise that, at this point in time, are not being publicly aired and, therefore, not being resolved. Without this, public servants in networks will continue working in ways that are constitutionally definable as 'risky', 'inappropriate' and even 'disloyal' (so they will continue to keep their heads below the parapets) when, in fact, what they are doing is acting entirely appropriately given emerging changes in the relationship between civil society and government in the 21 st century, and should be applauded and built on.

In order to demonstrate how and why this situation has arisen, it is necessary to identify some observable sociological and political features of 'working in policy networks' and the origins of these recent developments.

\section{Policy networks are extensive, intensive and porous and extend beyond the political executive}

Policy networks emerge as loose but self-conscious collectivities intensively engaged in a particular field of policy, usually centred in and around one or more government agencies. There is usually an active core membership, shading out into others whose engagement is more occasional. Membership is usually inclusive and extensive, comprising public servants who work in that field (including those from lead and other agencies) as well as providers, intermediaries, clients and stakeholders (including opponents). In other words, any policy network is not contained within one agency, even if it is centred there; it may flow across several and out into civil society and/or the economy (which is what gives networks their horizontal and lateral features). And their boundaries are often porous, unlike bureaucratic organisations that seek to define and close their edges. The trend towards formation of policy networks seems most apparent in (but may not be limited to) areas where policy is complex, uncertain, and crosses the traditional divisions between government agencies and relies on the cooperation of multiple participants, including those who are formally 'outside' government.

\section{Relationships within policy networks tend to be flat, collaborative and web-like}

Networks are built on 'partnerships' ${ }^{4}$ and not 'hierarchies'. Even if centred on one or more government agencies, the officials involved are not usually 'in command' (they may be 'leaders', but in the 21st-century sense of 'leading': see OECD, 2001a). Nor are they 'arm's length'. Even though the public servants participate officially as delegates of the minister and bearers of government's goals and objectives, and must sometimes seek to influence action in certain directions, there is a genuine interdependence and mutual reliance between all members in defining the problem and developing, implementing and evaluating solutions. They may provide the network with overall strategic goals, indicating the political, budgetary and managerial givens, and steer the process towards a certain framework of goals given by government priorities, but the relationships between network members are more like those between peers and colleagues, with web-like rather than pyramidal patterns of interaction (Gray, 2002; see also OECD, 2001b).

\section{Much of the work in policy networks pro- ceeds via collective policy learning}

Rather than being driven principally by research conducted by professional experts in back rooms, which is then assessed according to abstract decision criteria, partly because the public problems being dealt with are complex, multidimensional and multi-causal, policy development (and implementation and evaluation) in networks works in a mode more akin to a recursive journey of discovery than to the diagrams of a policy process textbook. Confronted by issues for which there

4 This word is in wide currency, yet may be misleading. Network members usually define each other as 'partners' and enact relatively equal relationships. Ultimately, however, the mandate of the elected government can be invoked, at which point officials, as delegates of the minister, will reassert authority or their vertical accountabilities, often with damaging consequences. There seems little doubt that non-government members of policy networks increasingly expect power relationships in the policy process to be equalised in fact and not just in rhetoric. 
are no easy answers, policy networks seek to explore and learn collectively, puzzling over the unknowns, envisaging scenarios, constructing hypotheses for action, trying them out and monitoring and evaluating the journey of discovery - a process more akin to 'trialling' and 'learning by doing' than to 'finding correct or scientifically-justifiable answers and applying them'. Experiential understanding and practical know-how brought by practitioners are valued and exploited as much as the technical input provided by professional researchers and evaluators. Multiple problem definitions and plural answers are recognised and taken as normal. Plausibility, precedence and achievability more than '(scientific) truth' are key decision criteria. 'What works in practice?' becomes the grail.

\section{Public servants participate in policy net- works as information brokers and resource fa- cilitators with lateral obligations to the other members of the network}

Formally, public servants participate in these policy networks as delegates of the minister, but the very character of the network relationships, the internal interdependence of the members and the exploratory nature of the work, means that, to be effective, public servants cannot simply enact that role. They cannot act in removed or distant or controlling ways, preserving the pristine elements of their role as 'public servant'. Network relationships are face-to-face, are built on engagement in a collective journey of puzzling, learning and strategy and are underpinned by a constant flow backwards and forwards of ideas, discussion, activities and documents in which public servants act as facilitators and brokers. Even where public servants bring knowledge of government intentions or comprehensive research or evaluation, they must and do engage with network members as something approaching 'partners in policy'. In doing so, they create mutual sets of lateral professional and knowledge-sharing obligations and responsibilities with other network members, obligations that can cut across those to ministers and cabinet (e.g. where government wants one thing but the answers emerging from the network propose another).

The critical thing about these developments is that for public servants engaged in policy networks, the relationships and interactions in which they participate and the social rules and professional practices through which they conduct their work are significantly different from those presupposed by logical derivation from classical Westminster conventions, or even the more nuanced forms that emerged in the 1970s and 80s. ${ }^{5}$ Policy networks are an organic form of organisation - in contrast to the mechanical form presupposed by Westminster - that are open, porous and semipublic rather than closed, impermeable and secret. The members interact as collaborators and peers; in effect, the non-government members become akin to partners within and around the political executive. For public servants, accountability to the minister remains a paramount principle, but it is now so surrounded with other obligations that core principles, no matter how often repeated, provide little guidance on how to act appropriately or how to reduce the stresses.

\section{Origins of these emerging realities: so- ciety and government}

Why is it that complex policy processes seem to be increasingly organised in and around policy networks, and that public servants are active participants in them as facilitators and brokers in a web of mutual relationships, rather than exclusively as emissaries of the government of the day, as technical experts in the service of the ministry? Where and why and how have these new realities emerged? The explanation is important, since it influences whether we should define them as positive or negative. ${ }^{6}$ Two possibilities can be identified: the first is as a response to increasing demands for participation in the policy process; the second, as a response to the problems of knowledge posed by complex public problems.

\section{The extension of political rights and the demand for participation}

With the progressive expansion of political rights in 20th-century social and liberal democracies, more and

5 It is possible that related shifts have occurred in relationships of public servants with (a) parliamentarians in select committees; (b) associate and non-government ministers in briefing cabinet committees; and (c) clients in case management - in the last case, including a new type of obligation (of service provision, as in service charters) that exists nowhere in the traditions of Westminster and yet which is a 21 st-century reality. These are not explored in this paper.

6 For example, some observers might criticise these developments as self-serving 'interest group politics'. Public choice theorists might see them as 'rent-seeking behaviour' by non-government interests and consider the possibility of 'capture'. As is clear from the following, I offer an alternative explanation and see these trends in positive terms. 
more citizens in their various roles demanded the right of input into matters of policy that affected them. The extension of suffrage to working adult males, then adult females, the rights of indigenous peoples, second-wave feminism, the conservation movement and recent talk of the rights of children and animals are illustrations. This trend continues (and has combined with the 'open government' movement that commenced in the 1970s). Less and less are citizens individually and collectively willing to have decisions thrust upon them; they demand the right at least to be consulted, and, increasingly, to participate in (and, conversely, to oppose and undermine) policy development, implementation and evaluation. As citizens force their way into policy through various forms of civil association, governments are finding it necessary and helpful to include them - necessary in recognising new claims to power based on the mobilisation of political rights, and helpful in the sense that they are better able to understand the issues and claim legitimacy for their decisions. Some of these new interactions occur around ministers, advisers and political parties, and some around and with state servants in their roles as policy advisers and implementers. Policy networks are the effect of these new patterns of interactions and blur the boundaries between the governors and the governed.

\section{Problems of knowing and acting}

Increasingly, the public problems to which government is expected to respond are complex, multi-factorial and look different from different perspectives. They can also appear recalcitrant, inexplicable and intractable (Ryan, 2003). The public sector knowledge sets and policy capabilities available to government tend to be indirect, technical and abstract, based as they are on standard forms of social science research and the application of academic disciplines to problem solving. Effective policy action demands that direct, experiential knowledge of the various dimensions of the issues and possible solutions is brought into the policy process, partly because it has the validity of direct experience and practical know-how, but also because complex problems with multiple causes need to be understood from diverse and relative viewpoints. This is also because scientifically credible knowledge is not necessarily useful or applicable knowledge; effective policy also needs non-positivist knowledge of practice and the conditions under which practice occurs, and is often better developed through action than discourse. Particularly when they stretch over policy development, implementation and evaluation, policy networks provide one way of combining conceptual and practice knowledge and creating ways of applying one to the other. ${ }^{7}$

In general, then, we can see that the rise and character of policy networks, and, more particularly, the practices that constitute today's public servants involved in them, has been a natural development, occurring partly as the polity responds to changes in the broader society; they are as much a product of government being 'acted upon' as government 'acting'. They are also a result of collective learning over time in the political executive. They have contributed to making the policy process more open, transparent and inclusive and less secret, and have pluralised and diffused the capacity to define and decide, all positive values from an 'open government' perspective. The public servant is at the centre of new sets of relationships and activities that involve a wider range of agents than previously, bringing more complex horizontal and lateral openings and obligations to bear that muddy the simple vertical and functional image of the 'technical arm of the executive', yet which seem essential to the functioning of a modern democracy.

They are natural developments in the constitutional relationships that make up the Aotearoa/New Zealand political system, and, in these respects at least, create a different power map to the traditional one. They are natural developments for sure, but not uncontested ones: governments have not always taken kindly to incursions by civil groupings into the policy process and are still inclined to assert the power of their perceived mandate when regarded as necessary. At such times, state servants in policy networks can find themselves to be the proverbial meat in the sandwich, in situations of considerable tension and risk. Where the stakes are high, we see attempts at reassertion of the 'traditional' line designed to ensure that state servants do not cross a certain line. The reminder to public servants by the state services commissioner at the time of the hikoi in April 2004, whilst nuanced, is probably a good example (Wintringham, 2004); it drew attention to the convention of not supporting groups that opposed government policy, yet made it difficult for those public

7 It also seems likely that a mature 'managing for outcomes' would strengthen these developments (Ryan, 2003). 
servants (particularly Māori) who maintained other types of network relationships with those who were on the streets.

Overall, though, it is not hard to argue that these are no more than recent steps in a long journey towards democratisation in which exclusive executive power is gradually reduced and the power of civil society and its parliamentary representation is progressively expanded not in a zero-sum way, but so that a society can consider public problems in all their complexity. In that sense, the shift towards policy networks, the pluralisation of the power to decide and the reconstitution of the public servant as policy process resource and facilitator are to be celebrated rather than cause for concern.

\section{Beyond 'Westminster': talk 'Aotearoa/ New Zealand'}

This paper argues that emerging forces impacting on and changing the constitutional role of public servants are natural developments resulting from ongoing changes in Aotearoa/New Zealand society. These forces seem likely to continue into the foreseeable future. In so far as these extend democracy and benefit the public good (and I would argue that they do), they are to be supported, even though they present considerable challenges to the structure and practice of public service and executive government.

The conventions of Westminster maintain a hold on our understandings of how best to relate the public service and cabinet. Yet, in truth, the core conventions apply at a high level of generality and speak to the relationships only between ministers and senior officials. The policy process these days is no longer the hermetic preserve of the executive, with public servants now engaged in extensive and intensive relationships with a wide range of government and non-government participants. Yet those founding conventions offer little guidance on how best to act. Some of our best up-and-coming public servants are struggling with the new realities, trying to respond appropriately to the more extensive demands emerging from civil society and to work in more effective and engaged ways, yet, while doing so, feel they are taking political risks. This is so primarily because the official touchstones are a collection of conventions forged in a different place and at a former time. There is no collective expression of these new realities, or even useful and ongoing discussion of societal changes, of what sort of polity we want to have, what we want our public servants to be and how we want them to act - in fact, we tend to shy away from anything that has a ring of 'constitutional debate'.

In order to grant permission to those who are trying to find new and 21st-century ways of conducting the policy process, and to enable discussion of what does and does not work or seem appropriate, we need to acknowledge and be open about the fact that public servants and citizens in various roles are treading new ground. We are, in fact, creating an Aotearoa/New Zealand system of government. The future, in this respect, is not something to be feared but something to be collectively constructed as our journey continues. It is time for the debate.

\section{References}

Cabinet Office (2001) Cabinet Manual, Wellington: Cabinet Office, Department of the Prime Minister and Cabinet

Eichbaum, C. and R. Shaw (2005) 'Why we should all be nicer to ministerial advisers', Policy Quarterly, 1 (4), pp.18-25

Giddens, A. (1984) The Social Constitution of Society, Cambridge: Polity Press

Gray, A. (2002) Integrated Service Delivery and Regional Co-ordination: a literature review, Wellington: Gray Matter Research Ltd, accessed from http://www.msd. govt.nz/work-areas/cross-sectoral-work/mosaics.html

Howlett, M. and M. Ramesh (1995) Studying Public Policy: policy cycles and policy subsystems, Ontario: Oxford University Press

James, C. (2002) The Tie That Binds: the relationship between ministers and chief executives, Wellington: Institute of Policy Studies

Ministry of Social Development (2003) Mosaics, Whakaahua Papariki: Key Findings and Good Practice Guide for Regional Co-ordination and Integrated Service Delivery, Wellington: MSD, accessed from http://www. msd.govt.nz/work-areas/cross-sectoral-work/mosaics. html

OECD (2001a) Public Sector Leadership for the 21st Century, Paris: Organisation for Economic Co-operation and Development

OECD (2001b) Citizens as Partners: information, 
consultation and public participation in policy-making, Paris: Organisation for Economic Co-operation and Development

Palmer, G. and M. Palmer (2004) Bridled Power: New Zealand's constitution and government, South Melbourne: Oxford University Press

Rhodes, R. (1997) Understanding Governance: policy networks, governance, reflexivity and accountability, Milton Keynes: Open University Press

Ryan, B. (2003) Learning MFO: managing for outcomes: the Queensland case, Brisbane: Institute of Public Administration Australia

Sabatier, P. (1988) 'An advocacy coalition framework of policy change and the role of policy-oriented learning therein', Policy Sciences, 21, pp.129-68

State Services Commission (1995) Public Service Principles, Conventions and Practice, Wellington: State Services Commission

White, N. (2005) 'Deconstructing cabinet collective solidarity', Policy Quarterly, 1 (4), pp.4-11

Wintringham, M. (2004) 'The foreshore and seabed policy - hikoi', Wellington: State Services Commission, accessable at http://www.ssc.govt.nz/display/document. asp? docid $=3826$

Bill Ryan is an Associate Professor in the School of Government at Victoria University of Wellington. His primary research interests lie in the broad area of governance and public management. He is currently Director of Programmes within the School of Government.

\section{INDIRECT TAXES IN NEW ZEALAND}

\section{An Institute of Policy Studies publication by John Creedy and Cath Sleeman}

Indirect Taxes in New Zealand presents the results of new empirical analyses relating to indirect taxation in New Zealand. The authors examine in detail the equity and efficiency effects of the existing tax system, and a range of policy reforms. These reforms include the abolition of excise taxes along with an increase in the GST rate, an increase in petrol taxation, and the imposition of carbon tax.

John Creedy and Cath Sleeman's analyses use economic models that allow for the fact that households change their consumption patterns when indirect patterns and prices change.

John Creedy is the Truby Williams Professor of Economics at Melbourne University. Cath Sleeman is an analyst at the Reserve Bank of New Zealand.

Published - July 2006

Format - B5 Paperback, pp 137

ISBN - 1-877347-11-6

Price - $\$ 25.00$ (incl P\&P within NZ)

To have a copy of Indirect Taxes in New Zealand and an invoice sent to you please email, phone, fax or mail your order to

\section{Institute of Policy Studies}

Victoria University of Wellington

Email ipos@vuw.ac.nz

Telephone +64 44635307

Fax +64 44637413

P0 Box 600, Wellington

New Zealand 